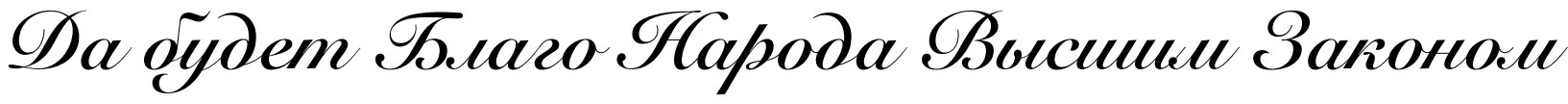

\section{Salus populi suprema lex esto}

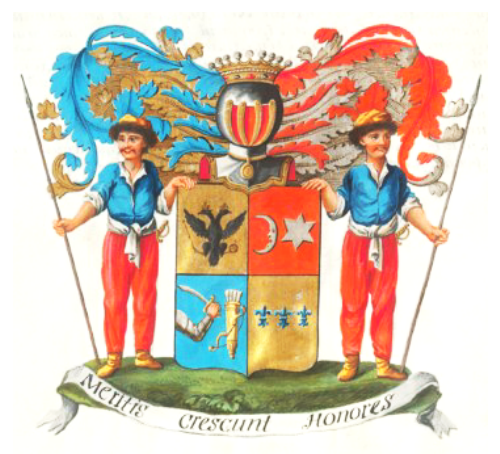

г. Ростов-на-Дону, Россия
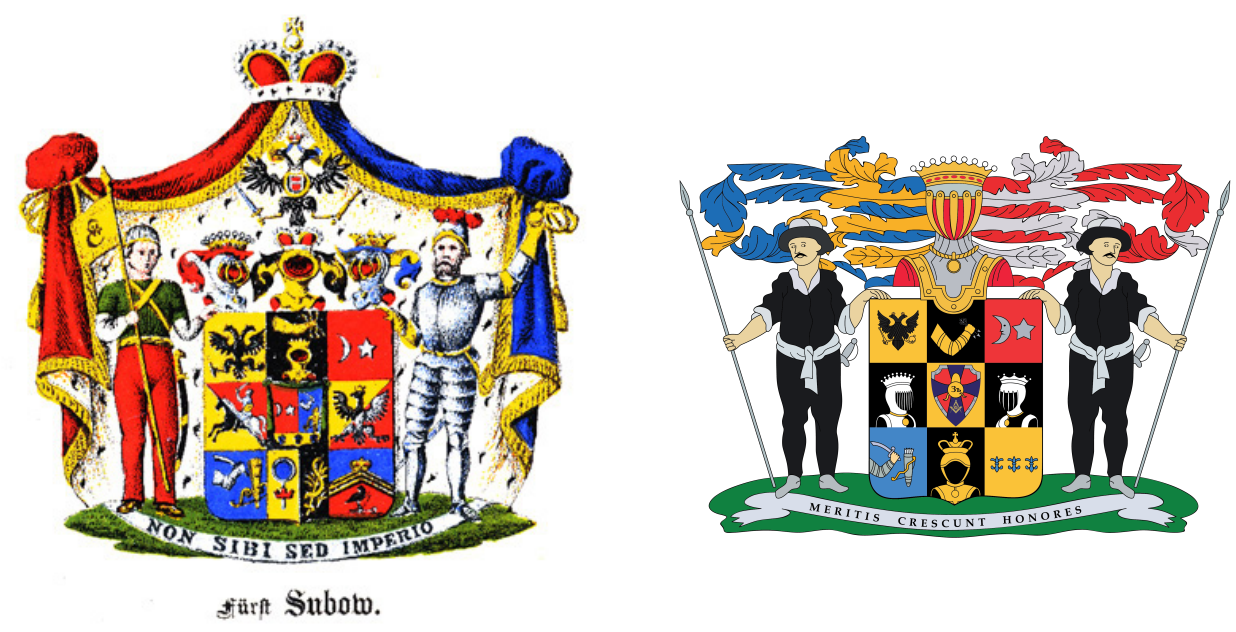

на правах рукописи

\section{МЕМОРАНДУМ}

о введении Цифровой валюты Центрального Банка - Цифрового рубля Центрального Банка Российской Федерации (CBDC-RU), приложение: Распоряжения клиент-банк, для исполнения в порядке ст. 48 Ф3 «О Центральном банке Российской Федерации ( Банке России)» от 10.07.2002г. № 86-Ф3 ; для контроля в порядке ч. 1 ст. 22 Ф3 «О валютном регулировании и валютном контроле от 10. 12. 2003 г. № 173-Ф3. для зачисления итоговой суммы 51062372699 (пятьдесят один миллиард шестьдесят два миллиона триста семьдесят две тысячи шестьсот девяносто девять) рублей 30 копеек цифровых руб̆лей и копеек CBDC-RU (Цифровая валюта Центрального Банка Российской Федерации)

двух Цифровых Финансовых Активов: Обеспеченного Цифрового Финансового Актива (ЦФА) № 20492 от 15 октября 2020 года и Обеспеченного Цифрового Финансового Актива (ЦФА) № 16738 от 24 ноября 2020 года

Актуальность данного исследования обусловлена по мнению автора Гриценко Сергея Леонидовича в соавторстве с гражданами Российской Федерации: Желтобрюховым Владимиром Викторовичем и Маркосьяном Вартаном Рафаэловичем тем, что развитие Цифровой валюты Центрального Банка - Цифрового рубля Центрального Банка Российской Федерации (CBDC-RU - аббревиатура обозначения, введённая авторами меморандума), далее по тексту CBDC-RU - одна из главнейших тенденций в финансовомонетарной сфере Российской Федерации, которая радикально изменит мир денег уже в ближайшее время. 
На сегодняшний момент исследованиями и разработками в области CBDC занимается более 80 \% центральных банков, при этом наиболее активно - КНР, Швеция и Канада. Уругвай, Эквадор и Украина завершили пилотные проекты розничных CBDC. Осуществляются пилотные проекты еще шести розничных CBDC: в Швеции, в Южной Корее, в Восточно-Карибском валютном союзе, на Багамских островах, в КНР и в Камбодже.

Прежде чем приступить к изложению вопросов, которым посвящен настоящий Меморандум, хотелось бы привести здесь Преамбулу Конституции Российской Федерации, принятой всенародным голосованием 12 декабря 1993 года с изменениями, одобренными в ходе общероссийского голосования 01 июля 2020 года, которая как нельзя точно отражает суть мотивов, которыми должен руководствоваться каждый гражданин Российской Федерации по отношению не только к принимаемой Конституции Российской Федерации, но и к Российской Федерации в целом - своей Родине: «Мы, многонациональный народ Российской Федерации, соединенные общей судьбой на своей земле, утверждая права и свободы человека, гражданский мир и согласие, сохраняя исторически сложившееся государственное единство, исходя из общепризнанных принципов равноправия и самоопределения народов, чтя память предков, передавших нам любовь и уважение к Отечеству, веру в добро и справедливость, возрождая суверенную государственность России и утверждая незыблемость ее демократической основы, стремясь обеспечить благополучие и процветание России, исходя из ответственности за свою Родину перед нынешним и будущими поколениями, сознавая себя частью мирового сообщества, принимаем КОНСТИТУЦИЮ РОССИЙСКОЙ ФЕДЕРАЦИИ».

В настоящем Меморандуме авторами были рассмотрены и исследованы следующие вопросы:

- что такое Цифровая валюта Центрального Банка - Цифровой рубль Центрального Банка Российской Федерации CBDC-RU;

- что такое Цифровой Финансовый Актив (ЦФА) (речь идет только об обеспеченных Цифровых Финансовых Активах);

- какую пользу для гражданского общества и Российского государства принесут Цифровая валюта Центрального Банка - Цифровой рубль Центрального Банка Российской Федерации (CBDC-RU) и Цифровой Финансовый Актив (ЦФА);

- какую пользу для каждого отдельного гражданина Российской Федерации принесут Цифровая валюта Центрального Банка - Цифровой рубль Центрального Банка Российской Федерации (CBDC-RU), Цифровой Финансовый Актив (ЦФА) и использование Российским государством Цифровой валюты Центрального Банка Цифрового рубля Центрального Банка Российской Федерации (CBDC-RU) и Цифрового Финансового Актива (ЦФА) - не ответив на первые три вопроса нельзя будет правильно, чётко и ясно ответить на четвертый вопрос.

При написании Меморандума авторы руководствовались действующими нормами Конституции Российской Федерации, Федеральных Законов Российской Федерации и иных нормативно-правовых актов Российской Федерации (за правовую основу берется законодательство Российской Федерации, а также принцип Верховенства Права), подвергнутых авторами детальному правовому анализу, сведениями, полученными из открытых источников через информационно-телекоммуникационную сеть «Интернет», существующей практикой по созданию обеспеченных Цифровых Финансовых Активов (ЦФА), которые являются обеспечением Цифровой валюты Центрального Банка Российской 
Федерации - Цифрового рубля Центрального Банка Российской Федерации (CBDC-RU), a также выводами, сделанными на основании реализации практики по созданию обеспеченных Цифровых Финансовых Активов (ЦФА).

Это стало возможным сделать и об этом можно говорить, поскольку гражданином Российской Федерации Гриценко Сергеем Леонидовичем в соавторстве с гражданами Российской Федерации: Желтобрюховым Владимиром Викторовичем и Маркосьяном Вартаном Рафаэловичем, на основании законодательства Российской Федерации и Верховенства Права созданы обеспеченные Цифровые Финансовые Активы (ЦФА), имеющие Знак Бренда:

1) Обеспеченный Цифровой Финансовый Актив (ЦФА) № 20492 от 15 октября 2020 года - на 7 (семи) листах - зарегистрирован в реестре нотариуса Ростовского-на-Дону нотариального округа Огульчанской Яны Михайловны № 61/323-н/61-2020-2-331, за что взыскано государственной пошлины (по тарифу): 100 рублей; уплачено за оказание услуг правого и технического характера: 1800 рублей. Уведомление о регистрации и постановке на реестровый учёт данного цифрового финансового актива (ЦФА) от Центрального Банка Российской Федерации 23.10.2020г. № Ц2/544677 - на 1 (одном) листе - зарегистрировано в реестре нотариуса Ростовского-на-Дону нотариального округа Огульчанской Яны Михайловны № 61/323-н/61-2020-2-372, за что взыскано государственной пошлины (по тарифу): 100 рублей; уплачено за оказание услуг правого и технического характера: 1800 рублей.

2) Обеспеченный Цифровой Финансовый Актив (ЦФА) № 16738 от 24 ноября 2020 года - на 7 (семи) листах - зарегистрирован в реестре нотариуса Ростовского-на-Дону нотариального округа Варавка Анны Николаевны № 61/68-н/61-2020-2-1269, за что взыскано государственной пошлины (по тарифу): 100 рублей; уплачено за оказание услуг правого и технического характера: 1800 рублей. Уведомление о регистрации и постановке на реестровый учёт данного цифрового финансового актива (ЦФА) от Центрального Банка Российской Федерации 14.12.2020г. № 10-8/16341 - на 1 (одном) листе - зарегистрировано в реестре нотариуса Ростовского-на-Дону нотариального округа Варавка Анны Николаевны № 61/68-н/61-2020-2-1409, за что взыскано государственной пошлины (по тарифу): 100 рублей; уплачено за оказание услуг правого и технического характера: 1800 рублей

Авторское право автора и соавторов зарегистрировано Министерством юстиции Российской Федерации по Ростовской области 17.11.2020 года № 5917-э, имеется Знак Бренда.

Кроме этого, гражданин Российской Федерации Гриценко Сергей Леонидович является автором и создателем следующих результатов интеллектуальной деятельности: Цифрового профиля гражданина (ЦПГ); Цифрового Финансового Актива (ЦФА); Цифрового профиля материалов дела (ЦПМД), имеющих регистрационные и нотариальные реестр № 61/191-н/61-2018-6-624 от 28 декабря 2018 года, основанных на Верховенстве Права, законов Российской Федерации и Международного права, являющимися продуктом личной интеллектуальной собственности человека и материальным финансовым (ЦФА) продуктом, каждого человека, запатентованного знака - «Знак АЗЪQ» № 017-0006493 от 05 июля 2017 года ISBN:978-5-4472-6564-9, нотариальный реестр № 1-600 от 03 марта 2016 года, имеющих Знак Бренда, нотариально удостоверенного в реестре нотариуса за № 61/191-н/ 61-2018-6-2028-6-622 от 28 декабря 2018 года. Обеспеченного цифрового финансового актива (ЦФА) 76,7 Mb, от 09 июля 2018 года № 201800124957, задепонированный в ФРС США и Министерстве юстиции США, правообладателем является гражданин Российской Федерации 
Гриценко Сергей Леонидович, 10 августа 1959 года рождения. Светокопия имеется в материалах гражданского дела № 2-2758/2020 УИД 61RS0007-01-2020-003250-60 (том № 1 листы дела 47-48), находящегося в Пролетарском районном суде города Ростова-на-Дону (федеральный суд общей юрисдикции), Россия, Ростовская область.

I.

Прежде чем приступить к рассмотрению и анализу вопроса о том, что такое Цифровая валюта Центрального Банка - Цифровой рубль Центрального Банка Российской Федерации (CBDC-RU - аббревиатура обозначения, введённая авторами меморандума), далее по тексту CBDC-RU, необходимо раскрыть такие понятия, как деньги, валюта, цифровая валюта и обосновать, как эти понятия соотносятся и взаимодействуют с нормами действующего законодательства Российской Федерации.

Согласно информации из открытых источников, полученной через информационнотелекоммуникационную сеть «Интернет»:

Деньги - это средство оплаты товаров и услуг, средство измерения стоимости, а также средство сохранения стоимости. Есть еще одно определение: Деньги - это всеобщий эквивалент, служащий мерой стоимости любых товаров и услуг, способный непосредственно на них обмениваться. По своей форме деньги могут быть особым товаром, ценной бумагой, знаком стоимости, различными благами или ценностями, записями по счетам.

Выделяют следующие виды денег:

- товарные (вещественные, натуральные, действительные, настоящие) деньги - это деньги, в роли которых выступает товар, обладающий самостоятельной стоимостью и полезностью;

- обеспеченные (разменные, представительские) деньги - это знаки или сертификаты, которые могут быть свободно обменены по предъявлению на фиксированное количество определённого товара или товарных денег, например, на золото или серебро;

- фиатные (символические, бумажные, декретные, декретированные, ненастоящие, необеспеченные) деньги - это деньги, не имеющие самостоятельной стоимости или она несоразмерна с номиналом; (Фиатные деньги не имеют ценности, но способны выполнять функции денег, поскольку государство принимает их в качестве уплаты налогов, а также объявляет законным платёжным средством на своей территории)

- электронные деньги - это означает перевод денег со счета на счет, начисление процентов и другие операции посредством передачи электронных сигналов без участия бумажных носителей денег. (Согласно п. 18 ст. 3 Федерального закона «О национальной платежной системе» от 27.06.2011 № 161-Ф3: «электронные денежные средства - денежные средства, которые предварительно предоставлены одним лицом (лицом, предоставившим денежные средства) другому лицу, учитывающему информацию о размере предоставленных денежных средств без открытия банковского счета (обязанному лицу), для исполнения денежных обязательств лица, предоставившего денежные средства, перед третьими лицами и в отношении которых лицо, предоставившее денежные средства, имеет право передавать распоряжения исключительно с использованием электронных средств платежа. При этом не являются электронными денежными средствами денежные средства, полученные организациями, осуществляющими профессиональную деятельность на рынке ценных бумаг, клиринговую деятельность, деятельность оператора финансовой платформы, деятельность по организации привлечения инвестиций, деятельность по управлению инвестиционными фондами, паевыми инвестиционными фондами и негосударственными пенсионными фондами, деятельность операторов информационных систем, в которых осуществляется 
выпуск цифровых финансовых активов, и (или) деятельность операторов обмена цифровых финансовых активов и осуществляющими учет информации о размере предоставленных денежных средств без открытия банковского счета в соответствии с законодательством, регулирующим деятельность указанных организаций)

- цифровые деньги - это денежные средства, существующие в цифровом формате, созданные с использованием криптографического кода, контролируемого Государством, на основе блокчейн технологий, с регистрацией на Международном уровне Банковского сообщества и Мировых Правительств.

Согласно информации из открытых источников, полученной через информационнотелекоммуникационную сеть «Интернет»:

- Валюта - это национальные, иностранные и международные деньги, как в наличной форме (в виде банкнот, казначейских билетов, монет), так и безналичной (на банковских счетах и в банковских вкладах), являющиеся законным средством платежа. То есть отличительным признаком Валюты является ее характеристика как действующее законное средство платежа - признанное и подтвержденное отдельным государством, рядом государств, всеми государствами, международным сообществом.

На основании изложенных определений денег и валюты можно сделать вывод, что:

- Цифровая Валюта - это денежные средства, существующие в цифровом формате, созданные с использованием криптографического кода, контролируемого Государством, на основе блокчейн технологии, являющиеся законным средством платежа.

На сегодняшний день в массовом сознании людей благодаря СМИ и информационнотелекоммуникационной сети «Интернет» бытует мнение, что цифровой валютой являются Биткоин, Лайткоин, Эфир, Риппл и т.д. Это ошибочное мнение, поскольку все эти псевдовалюты не являются законными средствами платежа, так как они не признаны и не подтверждены отдельным государством, рядом государств, всеми государствами либо международным сообществом. Спрос на эти псевдовалюты создан искусственно, а сами они имеют все признаки ничем не обеспеченной финансовой пирамиды. Применительно к законодательству Российской Федерации деятельность по распространению этих псевдовалют подпадает под санкции статьи 159 Уголовного Кодекса Российской Федерации «Мошенничество», так как в данном случае идет речь о завладении денежных средств путем обмана и злоупотребления доверием, и под санкции статьи 172.2 Уголовного Кодекса Российской Федерации «Организация деятельности по привлечению денежных средств и (или) иного имущества», поскольку в данном случае также речь идет об организация деятельности по привлечению денежных средств и (или) иного имущества физических лиц и (или) юридических лиц в крупном размере, при которой выплата дохода и (или) предоставление иной выгоды лицам, чьи денежные средства и (или) иное имущество привлечены ранее, осуществляются за счет привлеченных денежных средств и (или) иного имущества иных физических лиц и (или) юридических лиц при отсутствии инвестиционной и (или) иной законной предпринимательской или иной деятельности, связанной с использованием привлеченных денежных средств и (или) иного имущества, в объеме, сопоставимом с объемом привлеченных денежных средств и (или) иного имущества.

Пункт 1 и пункт 2 части 1 статьи 1 Федерального закона «О валютном регулировании и валютном контроле» от 10.12.2003 № 173-Ф3 вводят понятие валюты Российской 
Федерации и иностранной валюты. Валютой Российской Федерации являются денежные знаки в виде банкнот и монеты Банка России, находящиеся в обращении в качестве законного средства наличного платежа на территории Российской Федерации, а также изымаемые либо изъятые из обращения, но подлежащие обмену указанные денежные знаки, а также средства на банковских счетах и в банковских вкладах. Иностранной валютой являются денежные знаки в виде банкнот, казначейских билетов, монеты, находящиеся в обращении и являющиеся законным средством наличного платежа на территории соответствующего иностранного государства (группы иностранных государств), а также изымаемые либо изъятые из обращения, но подлежащие обмену указанные денежные знаки, а также средства на банковских счетах и в банковских вкладах в денежных единицах иностранных государств и международных денежных или расчетных единицах. Таким образом Федеральный закон «О валютном регулировании и валютном контроле» от 10.12.2003 № 173-Ф3 закрепляет, что Российская Федерация признает только те валюты, которые имеют статус законного средства платежа. Все иные денежные средства, которые не имеют статуса законного средства платежа, не являются валютой.

В соответствии с частью 1 статьи 75 Конституции Российской Федерации: «Денежной единицей в Российской Федерации является рубль. Денежная эмиссия осуществляется исключительно Центральным банком Российской Федерации. Введение и эмиссия других денег в Российской Федерации не допускаются».

С 1 января 2021 года вступил в силу Федеральный закон от 31.07.2020 года № 259-Ф3 «О цифровых финансовых активах, цифровой валюте и о внесении изменений в отдельные законодательные акты Российской Федерации» за исключением подпункта «б» пункта 3 статьи 17 указанного Федерального закона, который вступает в силу с 10 января 2021 года.

Согласно пункту 3 статьи 1 Федерального закона от 31.07.2020 года № 259-Ф3 «О цифровых финансовых активах, цифровой валюте и о внесении изменений в отдельные законодательные акты Российской Федерации»:

Цифровой валютой признается совокупность электронных данных (цифрового кода или обозначения), содержащихся в информационной системе, которые предлагаются и (или) могут быть приняты в качестве средства платежа, не являющегося денежной единицей Российской Федерации, денежной единицей иностранного государства и (или) международной денежной или расчетной единицей, и (или) в качестве инвестиций и в отношении которых отсутствует лицо, обязанное перед каждым обладателем таких электронных данных, за исключением оператора и (или) узлов информационной системы, обязанных только обеспечивать соответствие порядка выпуска этих электронных данных и осуществления в их отношении действий по внесению (изменению) записей в такую информационную систему ее правилам.

По мнению авторов настоящего Меморандума пункт 3 статьи 1 Федерального закона от 31.07.2020 года № 259-Ф3 «О цифровых финансовых активах, цифровой валюте и о внесении изменений в отдельные законодательные акты Российской Федерации» противоречит Конституции Российской Федерации и иным Федеральным законам.

Часть 1 статьи 75 Конституции Российской Федерации устанавливает, что денежной единицей в Российской Федерации является рубль. Это означает, что никаких иных средств платежа в Российской Федерации не допускается.

Нормы пункта 1 и пункта 2 части 1 статьи 1 Федерального закона «О валютном регулировании и валютном контроле» от 10.12.2003 № 173-Ф3 устанавливают, что только средства платежа являющиеся законными средствами платежа могут являться валютами. А поскольку Федеральный закон от 31.07.2020 года № 259-Ф3 «О цифровых финансовых активах, цифровой валюте и о внесении изменений в отдельные законодательные акты 
Российской Федерации» не вносит изменений в Федеральный закон «О валютном регулировании и валютном контроле» от 10.12.2003 № 173-Ф3, соответственно пункт 3 статьи 1 Федерального закона от 31.07.2020 года № 259-Ф3 «О цифровых финансовых активах, цифровой валюте и о внесении изменений в отдельные законодательные акты Российской Федерации» противоречит Федеральному закону «О валютном регулировании и валютном контроле» от 10.12.2003 № 173-ФЗ.

Статья 14 «Оборот цифровой валюты» Федерального закона от 31.07.2020 года № 259Ф3 «О цифровых финансовых активах, цифровой валюте и о внесении изменений в отдельные законодательные акты Российской Федерации» гласит:

1. Под организацией выпуска в Российской Федерации цифровой валюты понимается деятельность по оказанию услуг, направленных на обеспечение выпуска цифровой валюты, с использованием доменных имен и сетевых адресов, находящихся в российской национальной доменной зоне, и (или) информационных систем, технические средства которых размещены на территории Российской Федерации, и (или) комплексов программно-аппаратных средств, размещенных на территории Российской Федерации (далее - объекты российской информационной инфраструктуры).

2. Под выпуском цифровой валюты в Российской Федерации понимаются действия с использованием объектов российской информационной инфраструктуры и (или) пользовательского оборудования, размещенного на территории Российской Федерации, направленные на предоставление возможностей использования цифровой валюты третьими лицами.

3. Под организацией обращения в Российской Федерации цифровой валюты понимается деятельность по оказанию услуг, направленных на обеспечение совершения гражданско-правовых сделок и (или) операций, влекущих за собой переход цифровой валюты от одного обладателя к другому, с использованием объектов российской информационной инфраструктуры.

4. Организация выпуска и (или) выпуск, организация обращения цифровой валюты в Российской Федерации регулируются в соответствии с федеральными законами.

5. Юридические лица, личным законом которых является российское право, филиалы, представительства и иные обособленные подразделения международных организаций и иностранных юридических лиц, компаний и других корпоративных образований, обладающих гражданской правоспособностью, созданные на территории Российской Федерации, физические лица, фактически находящиеся в Российской Федерации не менее 183 дней в течение 12 следующих подряд месяцев, не вправе принимать цифровую валюту в качестве встречного предоставления за передаваемые ими (им) товары, выполняемые ими (им) работы, оказываемые ими (им) услуги или иного способа, позволяющего предполагать оплату цифровой валютой товаров (работ, услуг).

6. Требования лиц, указанных в части 5 настоящей статьи, связанные с обладанием цифровой валютой, подлежат судебной защите только при условии информирования ими о фактах обладания цифровой валютой и совершения гражданско-правовых сделок и (или) операций с цифровой валютой в порядке, установленном законодательством Российской Федерации о налогах и сборах.

7. В Российской Федерации запрещается распространение информации о предложении и (или) приеме цифровой валюты в качестве встречного предоставления за передаваемые ими (им) товары, выполняемые ими (им) работы, оказываемые ими (им) услуги или иного способа, позволяющего предполагать оплату цифровой валютой товаров (работ, услуг). 
По мнению авторов настоящего Меморандума статья 14 Федерального закона от 31.07.2020 года № 259-Ф3 «О цифровых финансовых активах, цифровой валюте и о внесении изменений в отдельные законодательные акты Российской Федерации» полностью противоречит Конституции Российской Федерации и подрывает основы государственности и суверенитета Российской Федерации, поскольку по факту позволяет любым лицам создавать свои средства платежа на территории Российской Федерации, что противоречит пункту «ж» статьи 71 Конституции Российской Федерации - «в ведении Российской Федерации находится денежная эмиссия». (Принцип Попандопуло из фильма «Свадьба в Малиновке»: «Бери, бери, я себе еще нарисую».) Согласно части 2 статьи 75 Конституции Российской Федерации: «Защита и обеспечение устойчивости рубля - основная функция Центрального банка Российской Федерации, которую он осуществляет независимо от других органов государственной власти». Статья 14 Федерального закона от 31.07.2020 года № 259-Ф3 «О цифровых финансовых активах, цифровой валюте и о внесении изменений в отдельные законодательные акты Российской Федерации» по факту лишает Центральный банк Российской Федерации функции защиты и обеспечения устойчивости рубля, так как позволяет создавать иные средства платежа в Российской Федерации.

Поскольку Цифровая Валюта - это денежные средства, существующие в цифровом формате, созданные с использованием криптографического кода, контролируемого Государством, на основе блокчейн технологии, являющиеся законным средством платежа, единственным эмитентом, согласно Конституции Российской Федерации, имеющим право ее выпускать является Центральный Банк Российской Федерации (Государство). Выпуск иных цифровых валют в Российской Федерации не допускается, иначе это противоречит Конституции Российской Федерации.

А поскольку согласно части 1 статьи 75 Конституции Российской Федерации денежной единицей в Российской Федерации является рубль, то сама Конституция Российской Федерации согласно части 2 статьи 75 накладывает обязанность на Центральный Банк Российской Федерации выпускать Цифровую валюту Центрального Банка Цифровой рубль Центрального Банка Российской Федерации (CBDC-RU).

Это будет новое денежное средство пришедшее на смену бумажным (наличным) деньгам, в век технологического прогресса развития Цифровых технологий и обучения Искусственного Интеллекта (где процесс контролируется и обеспечивается безопасностью Государством).

II.

\section{Что такое Цифровой Финансовый Актив (ЦФА)?}

Согласно пункту 2 статьи 1 Федерального закона от 31.07.2020 года № 259-Ф3 «О цифровых финансовых активах, цифровой валюте и о внесении изменений в отдельные законодательные акты Российской Федерации»:

Цифровыми финансовыми активами признаются цифровые права, включающие денежные требования, возможность осуществления прав по эмиссионным ценным бумагам, права участия в капитале непубличного акционерного общества, право требовать передачи эмиссионных ценных бумаг, которые предусмотрены решением о выпуске цифровых финансовых активов в порядке, установленном настоящим Федеральным законом, выпуск, учет и обращение которых возможны только путем внесения (изменения) записей в 
информационную систему на основе распределенного реестра, а также в иные информационные системы.

Это очень размытое и неясное определение Цифровых Финансовых Активов (ЦФА) из смысла которого следует, что Цифровыми Финансовыми Активами признаются цифровые права.

Что такое «цифровые права»? Согласно статье 141.1 Гражданского Кодекса Российской Федерации:

1. Цифровыми правами признаются названные в таком качестве в законе обязательственные и иные права, содержание и условия осуществления которых определяются в соответствии с правилами информационной системы, отвечающей установленным законом признакам. Осуществление, распоряжение, в том числе передача, залог, обременение цифрового права другими способами или ограничение распоряжения цифровым правом возможны только в информационной системе без обращения к третьему лицу.

2. Если иное не предусмотрено законом, обладателем цифрового права признается лицо, которое в соответствии с правилами информационной системы имеет возможность распоряжаться этим правом. В случаях и по основаниям, которые предусмотрены законом, обладателем цифрового права признается иное лицо.

3. Переход цифрового права на основании сделки не требует согласия лица, обязанного по такому цифровому праву.

Возникает следующий вопрос: «А что такое «информационная система, отвечающая установленным законом признакам»? И что такое «правила информационной системы»?

Согласно пункту 3 статьи 2 Федерального закона «Об информации, информационных технологиях и о защите информации» от 27.07.2006 года № 149-Ф3:

- информационная система - совокупность содержащейся в базах данных информации и обеспечивающих ее обработку информационных технологий и технических средств.

Согласно пункту 2 статьи 2 Федерального закона «Об информации, информационных технологиях и о защите информации» от 27.07.2006 года № 149-Ф3:

- информационные технологии - процессы, методы поиска, сбора, хранения, обработки, предоставления, распространения информации и способы осуществления таких процессов и методов.

Согласно части 1 статьи 4 Федерального закона «Об информации, информационных технологиях и о защите информации» от 27.07.2006 года № 149-Ф3:

- законодательство Российской Федерации об информации, информационных технологиях и о защите информации основывается на Конституции Российской Федерации, международных договорах Российской Федерации и состоит из настоящего Федерального закона и других регулирующих отношения по использованию информации федеральных законов.

Согласно пункту и) статьи 71 Конституции Российской Федерации:

- В ведении Российской Федерации находятся: ... информация, информационные технологии и связь...

Вышеизложенное позволяет сделать вывод, что регистрация Цифровых Финансовых Активов (ЦФА) (обеспеченный ЦФА), учет Цифровых Финансовых Активов (ЦФА), учет всех операций с Цифровыми Финансовыми Активами (ЦФА), 
ликвидация Цифровых Финансовых Активов (ЦФА) должны контролироваться государством - Российской Федерацией. То есть оператором информационной системы, в которой осуществляется выпуск Цифровых Финансовых Активов (ЦФА) должно быть государство - Российская Федерация. Все остальные Цифровые Финансовые Активы (ЦФА), выпущенные без контроля государства иными операторами информационной системы, кроме как государственным, являются незаконными.

Таким образом по мнению авторов настоящего Меморандума статья 5 Федерального закона от 31.07.2020 года № 259-Ф3 «О цифровых финансовых активах, цифровой валюте и о внесении изменений в отдельные законодательные акты Российской Федерации» полностью противоречит Конституции Российской Федерации и федеральным законам Российской Федерации и подрывает основы государственности и суверенитета Российской Федерации, поскольку разрешает функционирование юридических лиц, являющихся операторами информационной системы, в которой осуществляется выпуск цифровых финансовых активов (по факту данная деятельность приведет к подрыву экономики и сепаратизму). Соответственно все последующие статьи (6, 7, 8 и т. д.) Федерального закона от 31.07.2020 года № 259-Ф3 «О цифровых финансовых активах, цифровой валюте и о внесении изменений в отдельные законодательные акты Российской Федерации» также противоречат Конституции Российской Федерации и федеральным законам Российской Федерации, так как вытекают из статьи 5 Федерального закона от 31.07.2020 года № 259-Ф3 «О цифровых финансовых активах, цифровой валюте и о внесении изменений в отдельные законодательные акты Российской Федерации».

Но это не дает ответ на вопрос, что же такое Цифровой Финансовый Актив (ЦФА) (обеспеченный ЦФА)? Чтобы дать ответ на этот вопрос, нужно понимать, что такое Актив применительно к нашему случаю.

Согласно толковому словарю Ожегова: «Актив - это имущество, а также права на него, принадлежащие физическому или юридическому лицу».

Согласно терминологическому словарю банковских и финансовых терминов: «Актив это любой предмет, материальный или нематериальный, который представляет ценность для своего владельца. В большинстве случаев это либо наличные деньги, либо то, что может быть обращено в наличные деньги; исключение составляет досрочные выплаты ренты, местного налога на недвижимость или налога на автомобиль, т.е. платежи ранее установленного срока. Материальные активы включают в себя землю, здания или сооружения, машины и оборудование, арматуру и приспособления, товарные запасы, инвестиции, дебиторскую задолженность и наличные деньги; к нематериальным активам относятся "гудвил", патенты, авторские права и торговые марки. Однако в активы должна включаться только такая собственность, стоимость которой может быть установлена. Имущество, денежные средства и долговые требования, принадлежащие предприятию, фирме, компании. В актив входят: оборотный капитал (наличные деньги, инвестиции, дебиторская задолженность, сырье, полуфабрикаты), основной капитал (недвижимость, машины, станки, оборудование), отсроченные платежи (нехозяйственные ресурсы, например, расходы по устройству), нематериальные активы (патенты, деловая репутация компании, торговая марка, авторские права)».

Цифровой Финансовый Актив (ЦФА) - это актив, существующий в цифровом формате и имеющий стоимость, подтвержденную государством. Соответственно Цифровым Финансовым Активом может быть все, что имеет ценность начиная от иголок, вилок, ложек, одежды и заканчивая машинами, земельными участками, домами, квартирами, а также 
строительные материалы, полезные ископаемые, водные ресурсы, воздух (согласно Киотскому Протоколу), налоги, пошлины, акцизы, патенты, авторские права и т. д.

Чтобы перевести актив в цифровой формат, необходимо создать цифровой профиль материалов дела (ЦПМД) - оцифровать. В цифровой профиль материалов дела (ЦПМД) входит вся информация об активе: природа происхождения, описание характеристик: технических и правовых, - параметры, идентификация, стоимость.

Как пример, авторами настоящего Меморандума было создано два цифровых финансовых актива:

1) Обеспеченный Цифровой Финансовый Актив (ЦФА) № 20492 от 15 октября 2020 года на 7 (семи) листах - зарегистрирован в реестре нотариуса Ростовского-на-Дону нотариального округа Огульчанской Яны Михайловны № 61/323-н/61-2020-2-331;

Цифровым профилем материалов дела (ЦПМД) Обеспеченного Цифрового Финансового Актива (ЦФА) № 20492 от 15 октября 2020 года являются материалы гражданского дела № 2-2758/2020, УИД 61RS0007-01-2020-003250-60, находящегося в Пролетарском районном суде города Ростова-на-Дону (федеральный суд общей юрисдикции), по адресу: Россия, Ростовская область, город Ростов-на-Дону, площадь Карла Маркса, д. 10, Пролетарский районный суд г. Ростова-на-Дону (федеральный суд общей юрисдикции), а также цифровая регистрация материалов гражданского дела № 2-2758/2020, УИД 61RS0007-01-2020-003250-60 в Государственной автоматизированной системе Российской Федерации «Правосудие» (ГАС Правосудие). В материалах указанного гражданского дела содержится вся информация об Обеспеченном Цифровом Финансовом Активе (ЦФА) № 20492 от 15 октября 2020 года: природа возникновения, описание характеристик: технических и правовых, - параметры, идентификация, стоимость - порядка семи-восьми томов.

2) Обеспеченный Цифровой Финансовый Актив (ЦФА) № 16738 от 24 ноября 2020 года - на 7 (семи) листах - зарегистрирован в реестре нотариуса Ростовского-на-Дону нотариального округа Варавка Анны Николаевны № 61/68-н/61-2020-2-1269.

Цифровым профилем материалов дела (ЦПМД) Обеспеченного Цифрового Финансового Актива (ЦФА) № 16738 от 24 ноября 2020 года являются материалы гражданского дела № 2-2482/2020, УИД 61RS0009-01-2020-003414-44, находящегося в Азовском городском суде Ростовской области (федеральный суд общей юрисдикции), по адресу: Россия, Ростовская область, город Азов, улица Ленина, д. 67, Азовский городской суд Ростовской области (федеральный суд общей юрисдикции), а также цифровая регистрация материалов гражданского дела № 2-2482/2020, УИД 61RS0009-01-2020-003414-44 в Государственной автоматизированной системе Российской Федерации «Правосудие» (ГАС Правосудие). В материалах указанного гражданского дела содержится вся информация об Обеспеченном Цифровом Финансовом Активе (ЦФА) № 16738 от 24 ноября 2020 года: природа возникновения, описание характеристик: технических и правовых, - параметры, идентификация, стоимость - порядка трех-четырех томов.

Цифровым профилем материалов дела (ЦПМД) квартиры будет оцифровывание и объединение в одно оцифрованное дело технического и правового дела органа технической инвентаризации либо Кадастровой Палаты и правового дела Росреестра с указанием технических характеристик, правовых характеристик, адреса, кадастрового номера, всей правовой и технической истории объекта недвижимости и стоимости.

Цифровым профилем материалов дела (ЦПМД) объекта индивидуального жилищного строительства на земельном участке будет оцифровывание и объединение в одно 
оцифрованное дело здания, строения, сооружения либо зданий, строений, сооружений: технического и правового дела органа технической инвентаризации либо Кадастровой Палаты и правового дела Росреестра с указанием технических характеристик, правовых характеристик, адреса, кадастрового номера, всей истории объекта недвижимости, - а также земельного участка: землеустроительного дела Кадастровой Палаты и правового дела Росреестра с указанием технических характеристик, правовых характеристик, адреса, кадастрового номера, всей истории объекта недвижимости, - и указание общей стоимости.

Возможно создание Цифрового профиля материалов дела (ЦПМД) по отдельности. Главное перевести в цифровой формат.

Цифровым профилем материалов дела (ЦПМД) земельного участка будет являться продукт, созданный в результате оцифровывания землеустроительного или межевого дела, находящегося в Кадастровой Палате и правового дела Росреестра с указанием технических характеристик, правовых характеристик, адреса, кадастрового номера, всей правовой и технической истории объекта недвижимости с указанием стоимости

Цифровым профилем материалов дела (ЦПМД) ювелирных изделий будет являться продукт, созданный в результате оцифровывания сертификатов, QR-коды, описания пробы, камней (каратность, огранка, чистота), маркировка и стоимость.

Цифровым профилем материалов дела (ЦПМД) полезных ископаемых будет являться продукт, созданный в результате оцифровывания заключений разведочно-геологического института, название, описание местоположения (земельный участок с кадастровым номером, район, регион), размер запасов, качество и стоимость.

Цифровым профилем материалов дела (ЦПМД) завода, как сложной вещи будет являться продукт, созданный в результате оцифровывания всех зданий, строений, сооружений, корпусов, всего движимого имущества (станков, оборудования, техники и т.д.), земельного участка, всей материальной базы: всю техническую и правовую документацию, - с указанием инвентаризационных и кадастровых номеров, а также стоимость.

Цифровым профилем материалов дела (ЦПМД) любого налога будет являться продукт, созданный в результате оцифровывания предмета налогообложения, налоговая база, налоговая ставка и стоимость.

Таким образом - в цифровой формат можно перевести любое имущество (движимое и недвижимое): материальный и нематериальный актив, - которое имеет стоимость.

Определение стоимости Цифрового Финансового Актива (ЦФА) - это самый важный момент при выпуске Цифрового Финансового Актива (ЦФА). Поскольку регистрация Цифровых Финансовых Активов (ЦФА), учет Цифровых Финансовых Активов (ЦФА), учет всех операций с Цифровыми Финансовыми Активами (ЦФА), ликвидация Цифровых Финансовых Активов (ЦФА) контролируется государством - Российской Федерацией, государство несет ответственность за подлинность и обеспеченность Цифровых Финансовых Активов (ЦФА). Соответственно стоимость Цифровых Финансовых Активов (ЦФА) должна быть принята и подтверждена, гарантирована государством. Единственный верный и законный способ определения стоимости Цифрового Финансового Актива (ЦФА) - это уплата налогов государству. То есть с какой стоимости до перевода в цифровой формат уплачивался налог с этого актива.

В соответствии с Федеральным стандартом оценки «Цель оценки и виды стоимости (ФСО № 2), утвержденных Приказом № 298 от 20.05 .2015 г. Минэкономразвития РФ - результатом оценки является итоговая величина стоимости объекта оценки. Результат оценки может использоваться при определении сторонами цены для совершения сделки или иных действий с объектом оценки, в том числе при совершении 
сделок купли-продажи, передаче в аренду или залог, страховании, кредитовании, внесении в уставный (складочный) капитал, для целей налогообложения, при составлении финансовой (бухгалтерской) отчетности, реорганизации юридических лиц и приватизации имущества, разрешении имущественных споров и в иных случаях.

При осуществлении оценочной деятельности используются следующие виды стоимости объекта оценки:

- рыночная стоимость;

- инвестиционная стоимость;

- ликвидационная стоимость;

- кадастровая стоимость.

Понятия рыночной стоимости и кадастровой стоимости установлены Федеральным законом от 29 июля 1998 г. № 135-Ф3 «Об оценочной деятельности в Российской Федерации».

Под рыночной стоимостью объекта оценки понимается наиболее вероятная цена, по которой данный объект оценки может быть отчужден на открытом рынке в условиях конкуренции, когда стороны сделки действуют разумно, располагая всей необходимой информацией, а на величине цены сделки не отражаются какие-либо чрезвычайные обстоятельства, то есть когда:

одна из сторон сделки не обязана отчуждать объект оценки, а другая сторона не обязана принимать исполнение;

стороны сделки хорошо осведомлены о предмете сделки и действуют в своих интересах;

объект оценки представлен на открытом рынке посредством публичной оферты, типичной для аналогичных объектов оценки;

цена сделки представляет собой разумное вознаграждение за объект оценки и принуждения к совершению сделки в отношении сторон сделки с чьей-либо стороны не было;

платеж за объект оценки выражен в денежной форме.

Под кадастровой стоимостью понимается стоимость, установленная в результате проведения государственной кадастровой оценки или в результате рассмотрения споров о результатах определения кадастровой стоимости либо определенная в случаях, предусмотренных статьей 24.19 Федерального закона от 29 июля 1998 г. № 135-Ф3 «Об оценочной деятельности в Российской Федерации».

С целью предотвращения необоснованного завышения стоимости Цифрового Финансового Актива (ЦФА), необходима обязательная проверка на соответствие реальной стоимости службой по финансовому мониторингу. В связи с тем, что - Федеральная Служба по Финансовому Мониторингу Российской Федерации - это федеральный орган исполнительной власти Российской Федерации, осуществляющий функции по противодействию легализации (отмыванию) доходов, полученных преступным путем, и финансированию терроризма, а также по выработке государственной политики, нормативноправовому регулированию и координации деятельности в этой сфере иных федеральных органов исполнительной власти.

Если вообще не платились налоги по причине, что скрывалось это имущество с целью уйти от налогообложения, - государство вообще не признает данный актив Цифровым Финансовым Активом (ЦФА), принадлежащим этому лицу, и может заявить свои права на это имущество.

При выпуске и регистрации Цифрового Финансового Актива (ЦФА) обязательно выполнение следующих условий: 
- уплата казначейского сбора при выпуске Цифрового Финансового Актива (ЦФА). При выпуске Обеспеченного Цифрового Финансового Актива (ЦФА) № 20492 от 15 октября 2020 года уплачена «Государственная пошлина в суд» (казначейский сбор КБК: 18210803010011000110) в размере 2000 (две тысячи ) рублей - в УФК по Ростовской области (межрайонная ИФНС России № 25 по Ростовской области) 26.06.2020 года в 09 часов 59 минут (МСК), квитанция СУИП: 800714103060WDNL, принята и зарегистрирована в материалах гражданского дела № 2-2758/2020, УИД 61RS0007-01-2020-003250-60, находящегося в Пролетарском районном суде города Ростова-на-Дону (федеральный суд общей юрисдикции) - том 1 (первый) лист дела 40 (сорок). При выпуске Обеспеченного Цифрового Финансового Актива (ЦФА) № 16738 от 24 ноября 2020 года уплачена «Государственная пошлина в суд» (казначейский сбор КБК: 18210803010011000110) в размере 1000 (одна тысяча) рублей - в УФК по Ростовской области (межрайонная ИФНС России № 18 по Ростовской области) 16.11.2020 года в 17 часов 02 минуты (МСК), квитанция СУИП: 351553850523LDRL, принята и зарегистрирована в материалах гражданского дела № 2-2482/2020, УИД 61RS0009-01-2020-003414-44, находящегося в Азовском городском суде Ростовской области (федеральный суд общей юрисдикции).

- уплата государственной пошлины при регистрации Цифрового Финансового Актива (ЦФА). Обеспеченный Цифровой Финансовый Актив (ЦФА) № 20492 от 15 октября 2020 года - на 7 (семи) листах - зарегистрирован в реестре нотариуса Ростовского-на-Дону нотариального округа Огульчанской Яны Михайловны № 61/323-н/61-2020-2-331, за что взыскано государственной пошлины (по тарифу): 100 рублей; уплачено за оказание услуг правого и технического характера: 1800 рублей. Обеспеченный Цифровой Финансовый Актив (ЦФА) № 16738 от 24 ноября 2020 года - на 7 (семи) листах - зарегистрирован в реестре нотариуса Ростовского-на-Дону нотариального округа Варавка Анны Николаевны № 61/68-н/61-2020-2-1269, за что взыскано государственной пошлины (по тарифу): 100 рублей; уплачено за оказание услуг правого и технического характера: 1800 рублей.

При отсутствии уплаты казначейского сбора и государственной пошлины государство отказывает в регистрации и подтверждении признания актива-имущества Цифровым Финансовым Активом (ЦФА).

Таким образом, Цифровой Финансовый Актив (ЦФА) - это актив, существующий в цифровом формате и имеющий стоимость, подтвержденную государством, при выпуске и регистрации которого уплачен казначейский сбор и государственная пошлина.

Поскольку стоимость Цифровых Финансовых Активов (ЦФА) принимается и подтверждается государством путем уплаты налогов, соответственно реестр регистрации Цифровых Финансовых Активов (ЦФА), учета Цифровых Финансовых Активов (ЦФА), учета всех операций с Цифровыми Финансовыми Активами (ЦФА), ликвидации Цифровых Финансовых Активов (ЦФА) должен вестись Федеральной Налоговой Службой Российской Федерации.

III.

Какую пользу для гражданского общества и Российского государства принесут Цифровая валюта Центрального Банка - Цифровой рубль Центрального Банка Российской Федерации (CBDC-RU) и Цифровой Финансовый Актив (ЦФА)?

В соответствии с пунктом 1 статьи 8 Конституции Российской Федерации: «В Российской Федерации гарантируются единство экономического пространства, свободное 
перемещение товаров, услуг и финансовых средств, поддержка конкуренции, свобода экономической деятельности».

В соответствии с пунктом е) статьи 71 Конституции Российской Федерации в ведении Российской Федерации находится установление основ федеральной политики и федеральные программы в области экономического развития Российской Федерации.

В соответствии с пунктом ж) статьи 71 Конституции Российской Федерации в ведении Российской Федерации находятся установление правовых основ единого рынка; финансовое, валютное, кредитное, таможенное регулирование, денежная эмиссия, основы ценовой политики; федеральные экономические службы, включая федеральные банки.

Согласно статье 75.1 Конституции Российской Федерации: «В Российской Федерации создаются условия для устойчивого экономического роста страны и повышения благосостояния граждан, для взаимного доверия государства и общества, гарантируются защита достоинства граждан и уважение человека труда, обеспечиваются сбалансированность прав и обязанностей гражданина, социальное партнерство, экономическая, политическая и социальная солидарность».

Согласно пункту 2 статьи 75 Конституции Российской Федерации: «Защита и обеспечение устойчивости рубля - основная функция Центрального банка Российской Федерации, которую он осуществляет независимо от других органов государственной власти».

Согласно пункту б) статьи 114 Конституции Российской Федерации Правительство Российской Федерации обеспечивает проведение в Российской Федерации единой финансовой, кредитной и денежной политики.

Согласно пунктам 1), 2), 3), 4) статьи 18 Федерального конституционного закона от 06.11.2020 года № 4-ФКЗ «О Правительстве Российской Федерации» Правительство Российской Федерации:

1) осуществляет в соответствии с Конституцией Российской Федерации, федеральными конституционными законами, федеральными законами, указами, распоряжениями и поручениями Президента Российской Федерации регулирование экономических процессов;

2) обеспечивает единство экономического пространства и свободу экономической деятельности, свободное перемещение товаров, услуг и финансовых средств;

3) прогнозирует социально-экономическое развитие Российской Федерации, разрабатывает и реализует программы развития отраслей экономики;

4) вырабатывает государственную структурную и инвестиционную политику, принимает меры по ее реализации.

Согласно статье 3 Федерального закона «О Центральном банке Российской Федерации (Банке России)» от 10.07.2002 года № 86-Ф3 целями деятельности Банка России являются:

- защита и обеспечение устойчивости рубля;

- развитие и укрепление банковской системы Российской Федерации;

- обеспечение стабильности и развитие национальной платежной системы;

- развитие финансового рынка Российской Федерации;

- обеспечение стабильности финансового рынка Российской Федерации.

- Получение прибыли не является целью деятельности Банка России.

Глава VII Федерального закона «О Центральном банке Российской Федерации (Банке России)» от 10.07.2002 года № 86-Ф3 полностью посвещена и регламентирует деятельность Центрального Банка Российской Федерации в области денежно-кредитной политики. Согласно определению «Денежно-кредитной политики», выставленному на сайте Центрального Банка Российской Федерации (https://cbr.ru/DKP/): «Денежно-кредитная 
политика - часть государственной экономической политики, направленной на повышение благосостояния российских граждан. Ее приоритетом является обеспечение ценовой стабильности, то есть стабильно низкой инфляции».

Согласно части 1 статьи 5 Федерального закона «О валютном регулировании и валютном контроле» от 10.12.2003 года № 173-Ф3: «Органами валютного регулирования в Российской Федерации являются Центральный банк Российской Федерации и Правительство Российской Федерации».

Данное перечисление норм права Российского законодательства было сделано не с целью просто процитировать законы, а с целью указать на наличие пробела в законодательстве в связи с тем, о чем пойдет ниже речь.

Чем в настоящее время обеспечен Российский рубль? Согласно информации из открытых источников, полученной через информационно-телекоммуникационную сеть «Интернет»:

- Российский рубль ничем не обеспечен.

Этот же вывод можно сделать из анализа действующего Российского законодательства - нормы которого приведены выше и нигде не сказано об обеспечении Российского рубля.

Большинство статей в информационно-телекоммуникационной сети «Интернет» посвящены попыткам проанализировать существующую ситуацию и найти способ обеспечить Российский рубль золотым стандартом. Однако, как признают сами авторы этих публикаций - в ближайшее время это сделать невозможно, пока не будет найдена альтернатива золотому стандарту.

На сегодняшний день все страны в мире пользуются фиатными деньгами, а также электронными деньгами, которые привязаны к фиатным деньгам.

Совсем иная природа у Цифровой валюты Центрального Банка - Цифрового рубля Центрального Банка Российской Федерации (CBDC-RU).

Цифровой рубль Центрального Банка Российской Федерации (CBDC-RU) обеспечен Цифровыми Финансовыми Активами (ЦФА).

Кто-то может высказать сомнения, что активы, переведенные в цифровой формат, могут быть израсходованы (например - недра), могут быть съедены (например - продукты питания), могут погибнуть в результате несчастного случая (дом сгорел) и т. д., то есть обеспечение ненадежное.

Есть самый простой аргумент надежности и обеспечения Цифрового рубля Центрального Банка Российской Федерации (CBDC-RU).

Пункт 3 статьи 4 Конституции Российской Федерации: «Российская Федерация обеспечивает целостность и неприкосновенность своей территории».

Статья 67 Конституции Российской Федерации:

1. Территория Российской Федерации включает в себя территории ее субъектов, внутренние воды и территориальное море, воздушное пространство над ними. На территории Российской Федерации в соответствии с федеральным законом могут быть созданы федеральные территории. Организация публичной власти на федеральных территориях устанавливается указанным федеральным законом.

2. Российская Федерация обладает суверенными правами и осуществляет юрисдикцию на континентальном шельфе и в исключительной экономической зоне 
Российской Федерации в порядке, определяемом федеральным законом и нормами международного права.

2.1. Российская Федерация обеспечивает защиту своего суверенитета и территориальной целостности. Действия (за исключением делимитации, демаркации, редемаркации государственной границы Российской Федерации с сопредельными государствами), направленные на отчуждение части территории Российской Федерации, а также призывы к таким действиям не допускаются.

3. Границы между субъектами Российской Федерации могут быть изменены с их взаимного согласия.

Единственное, что не изменится никогда в Российской Федерации - это территория Российской Федерации - земля. Все остальное - это уже производное от земли.

Согласно ст. 128 Гражданского Кодекса Российской Федерации - «к объектам гражданских прав относятся вещи (включая наличные деньги и документарные ценные бумаги), иное имущество....».

К недвижимым вещам (недвижимое имущество, недвижимость) в соответствии с п. 1 ст. 130 Гражданского Кодекса Российской Федерации относятся в том числе земельные участки.

В соответствии с нормами п.1 ст. 16 Земельного Кодекса Российской Федерации, п. 2 ст. 214 Гражданского Кодекса Российской Федерации - «земля и другие природные ресурсы, не находящиеся в собственности граждан, юридических лиц, либо муниципальных образований, являются государственной собственностью». При этом ст. 3.1 Федерального закона № 137-Ф3 от 25.10.2001 г. «О введении в действие Земельного Кодекса Российской Федерации» и п. 2. ст. 16 Земельного Кодекса Российской Федерации определяют возможность принадлежности земли к федеральной собственности, собственности субъектов Российской Федерации, муниципальной собственности.

Непосредственно сам земельный участок как объект недвижимости рассматривается в гражданском праве. Вместе с тем, для земельного права существенным фактором выступает принадлежность земельного участка к природному объекту, природным ресурсам.

Ведь Земля - это среда обитания человека, включающая в себя земную и воздушную оболочки земного шара, его недра, поверхность и ландшафт, животный мир и растительный мир. Под термином «земля» надо понимать и часть земной коры, ее поверхностные слои, непосредственно расположенные над недрами, в пределах территории суверенитета государства. Понятие «земля» отлично от термина «земельный участок», который подлежит применению в действующем российском законодательстве.

Несмотря на различия в правовом режиме, между участком недр и земельным участком существует физическая взаимосвязь, которая не прекращается даже при их юридическом обособлении. Так, в соответствии с Положением об установлении и изменении границ участков недр, предоставленных в пользование: утв. Постановлением Правительства Российской Федерации от 3 мая 2012 г. № 429 - участок недр представляет собой геометризованный блок, который индивидуализируется с помощью географических координат. Логично, что индивидуализация участка недр не может быть осуществлена в отрыве от земельного участка над ним.

Установление соотношения прав на недра и прав на поверхность над ними на основе принципа акцессии (от лат. «асcessio» - приращение) усматривалось еще в Уставе Горном Российской империи 1832 г., устанавливающем, что «право полной частной собственности в имуществах недвижимых объемлет не одну поверхность земли, но и самое ее недро» (ст. 236). 
В действующем законодательстве Российской Федерации закреплена «землецентричная» концепция недвижимости: земля рассматривается как ключевой элемент общего понятия недвижимости и как критерий отнесения того или иного объекта к объектам недвижимого имущества: такими являются объекты, настолько прочно связанные с землей, что их перемещение невозможно без несоразмерного ущерба их назначению (ст. 130 Гражданского Кодекса Российской Федерации).

Понимание земли не только как природного объекта, охраняемого в качестве важнейшей составной части природы, природного ресурса, объекта права собственности и иных прав на землю, но и как недвижимого имущества закреплено в качестве первого принципа земельного законодательства (ст. 1 Земельного Кодекса Российской Федерации).

Таким образом, проведенный анализ действующего законодательства относительно соотношения земли и недр как объектов права позволяет сделать ряд принципиальных выводов:

- самостоятельным объектом отношений в сфере недвижимости (объектом недвижимости) является именно земельный участок; право собственности на земельный участок в его границах распространяется на все, что находится над и под поверхностью этого участка, если иное не предусмотрено специальными законами и не нарушает прав других лиц;

- участок недр не является объектом недвижимости; специфический правовой режим недр связан непосредственно со свойствами, способными удовлетворить потребности лиц, обусловленными наличием соответствующих природных ресурсов в них.

Кроме того, государство в лице уполномоченных органов получает прибыль от участия в экономическом обороте земельных участков федеральной собственности (земель казны).

В настоящее время под гражданским оборотом понимают систему юридически значимых действий, в т.ч. сделок, которые обеспечивают и опосредуют существующие в данном государстве экономические отношения. При этом - гражданский оборот является правовой формой экономического оборота.

Важным свойством объектов гражданского оборота является способность, позволяющая удовлетворять потребности участников гражданского оборота.

Объекты гражданских прав в силу своих природных свойств существуют вне всякой зависимости от правовой действительности, между тем в случае неимения правового режима они попросту теряют свое функциональное предназначение, так как больше не могут выступать в качестве средств удовлетворения потребностей субъектов.

Субъектами в контексте гражданского оборота могут выступать физические и юридические лица, а также публично-правовые образования (Российская Федерация, субъекты Российской Федерации и муниципальные образования).

В связи с вышеизложенным по мнению соавторов, за основу - стандарт цифрового рубля, в качестве обеспечения необходимо взять стоимость 1 (одного) квадратного метра земли - территории Российской Федерации.

Гражданин Российской Федерации Гриценко Сергей Леонидович в 2018 году задепонировал в ФРС США и Министерстве юстиции США стоимость 1 (одного) квадратного метра земли - территории Российской Федерации, в размере 147 рублей. Это было сделано с целью закрепления на международном уровне стандарта рубля - валюты Российской Федерации. Сумма 147 рублей была выведена, обоснована и доказана Гриценко Сергеем Леонидовичем на основании законодательства Российской Федерации и судебных актов судебной системы Российской Федерации (восполнен пробел Уильяма Петти - отца современной экономики). 
Таким образом не Цифровой рубль Центрального Банка Российской Федерации (CBDC-RU) должен быть привязан к нынешним фиатным рублям, пока они не переведены в цифровой формат, а все рубли должны быть привязаны к Цифровому рублю Центрального Банка Российской Федерации (CBDC-RU).

В геополитическом плане Российская Федерация будет обладать самой твердой и обеспеченной валютой - Цифровым рублем Центрального Банка Российской Федерации (CBDC-RU). Экономика Российской Федерации перестает зависеть от доллара США и других иностранных валют (все иностранные валюты являются фиатными денежными средствами и ничем не обеспечены), от колебаний курса иностранных валют, все сделки с иностранными партнерами должны производиться только в валюте Российской Федерации Цифровых рублях Центрального Банка Российской Федерации (CBDC-RU). Экономическая независимость Российской Федерации укрепит политическую независимость, что дает возможность Российской Федерации быть ведущим экономическим и геополитическим игроком на международной арене.

Поскольку Цифровой рубль Центрального Банка Российской Федерации (CBDCRU) обеспечен стоимостью 1 (одного) квадратного метра земли - территории Российской Федерации - это дает колоссальный денежный потенциал государству Российской Федерации. Российская Федерация как государство обладает самой большой в мире территорией - 17125191 квадратный километр (информация взята из открытых источников через информационно-телекоммуникационную сеть «Интернет»). В каждом 1 (одном) квадратном километре 1000000 (один миллион) квадратных метров.

Выпуск Цифровой валюты Центрального Банка - Цифрового рубля Центрального Банка Российской Федерации (CBDC-RU) происходит с использованием криптографического кода на основе блокчейн технологии, то есть денежные средства Цифрового рубля Центрального Банка Российской Федерации (CBDC-RU) существет в цифровом формате. В связи с этим отпадает необходимость в выпуске наличных денежных средств - банкнот и монет, что уже является экономически выгодным для Российской Федерации. Это и будет новое денежное средство пришедшее на смену бумажным (наличным) деньгам, в век технологического прогресса развития Цифровых технологий и обучения Искусственного Интеллекта (где процесс контролируется и обеспечивается безопасностью Государством).

Использование Цифровой валюты Центрального Банка - Цифрового рубля Центрального Банка Российской Федерации (CBDC-RU) максимально исключит возможность нецелевого расходования бюджетных денежных средств и полностью исключит возможность хищения денежных средств из бюджета. Каждый Цифровой рубль Центрального Банка Российской Федерации (CBDC-RU) обладает своим кодом, а благодаря блокчейн технологии у государства будет возможность проследить все денежные операции и конечного получателя денежных средств. Точно также благодаря блокчейн технологии будет исключена возможность давать и получать взятки, потому что у государства опять же будет возможность проследить все денежные операции.

При переводе фиатных рублей (наличных и электронных) в Цифровую валюту Центрального Банка - Цифрового рубля Центрального Банка Российской Федерации (CBDC-RU) у государства - Российской Федерации возникает право проверить законность происхождения этих фиатных рублей (например - получены ли эти денежные средства преступным путем либо уплачивались ли налоги с этих денежных средств и т. д.), и в случае отсутствия легитимной основы происхождения денежных средств, государство вправе 
изъять их либо признать недействительными и аннулировать. Это применимо и к олигархам, сколотившим свои состояния на разворовывании бюджетных средств, и к чиновникам, обладающим имуществом, явно купленным не за чиновничью зарплату, и к банкирам, у которых на личных счетах лежат крупные суммы денег (фиатные), т. д.

Цифровая валюта Центрального Банка - Цифровой рубль Центрального Банка Российской Федерации (CBDC-RU) наполнит бюджет Российской Федерации, позволит сохранить бюджетные средства путем контроля и целевого расходования денежных средств, что в свою очередь позволит государству - Российской Федерации избавиться от таких «паразитов» как Пенсионный фонд, фонд социального страхования и других фондов, поскольку позволит государству производить выплаты гражданам и населению напрямую из бюджета благодаря блокчейн технологии. В свою очередь это освободит малый и средний бизнес от уплаты пенсионных взносов, взносов в различные фонды, и останется только оплата подоходного налога либо налога на прибыль, что опять же в свою очередь позволит бизнесу работать в «открытую», платить налоги государству (налоговый платеж будет только один) и достойные так называемые «белые» зарплаты своим работникам (с удержанием подоходного налога без всяких иных платежей). Это будет способствовать стабильности и экономическому росту общества и государства, росту так называемого среднего класса.

При использовании в расчетах Цифровой валюты Центрального Банка Цифрового рубля Центрального Банка Российской Федерации (CBDC-RU) Федеральная Налоговая Служба Российской Федерации самостоятельно будет рассчитывать, удерживать и списывать налоги с плательщиков налогов не обременяя последних необходимостью самим подавать декларации, обращаться к бухгалтерам, получать квитанции, производить оплаты налога.

Можно перечислять все стороны общественной и государственной сферы деятельности, но одно несомненно - польза от использования Цифровой валюты Центрального Банка - Цифрового рубля Центрального Банка Российской Федерации (CBDC-RU) будет однозначно очень большая, поскольку позволит государству контролировать потоки денежных средств (принцип - не нарушай закон и живи спокойно). Тем более статья 2 Конституции Российской Федерации закрепляет следующую основу конституционного строя Российской Федерации: «Человек, его права и свободы являются высшей ценностью. Признание, соблюдение и защита прав и свобод человека и гражданина - обязанность государства».

IV.

Какую пользу для каждого отдельного гражданина Российской Федерации принесут Цифровая валюта Центрального Банка - Цифровой рубль Центрального Банка Российской Федерации (CBDC-RU), Цифровой Финансовый Актив (ЦФА) и использование Российским государством Цифровой валюты Центрального Банка Цифрового рубля Центрального Банка Российской Федерации (CBDC-RU) и Цифрового Финансового Актива (ЦФА)?

Во-первых, использование Цифровой валюты Центрального Банка - Цифрового рубля Центрального Банка Российской Федерации (CBDC-RU) (обеспеченного рубля) гарантирует экономическую стабильность в обществе и государстве для каждого гражданина (уверенность в завтрашнем дне).

Во-вторых, использование Цифровой валюты Центрального Банка - Цифрового рубля Центрального Банка Российской Федерации (CBDC-RU) для пользы среднего и 
малого бизнеса уже говорилось выше. Каждый гражданин, решивший заняться бизнесом либо занимающийся бизнесом, избавляется от всех лишних платежей, кроме налога, а также избавляется от всех поборов со стороны чиновников и полиции - взятки исключаются.

В-третьих, каждый гражданин Российской Федерации обладает каким-либо имуществом (дом, квартира, машина, компьютер, мобильный телефон, ювелирные изделия и т. д.) - это актив каждого гражданина, который может быть преобразован в Цифровой Финансовый Актив (ЦФА). В случае преобразования в Цифровой Финансовый Актив (ЦФА) и включения, скажем так, в актив государства в качестве обеспечения Цифрового рубля Центрального Банка Российской Федерации (CBDC-RU), государство должно будет выплачивать каждому гражданину процент пусть даже по ставке рефинансирования за пользования его Цифровым Финансовым Активом (ЦФА) (естественно за вычетом налога на прибыль, потому что это доход гражданина). Данный фактор позволит улучшить благосостояние населения и каждого гражданина в отдельности. К тому же это обстоятельство заставит каждого гражданина более ответственно относиться к своему имуществу, являющемуся обеспечением его Цифрового Финансового Актива (ЦФА), стараться его сохранить и поддерживать в нормальном состоянии, чтобы его стоимость не упала, в противном случае уменьшится стоимость Цифрового Финансового Актива (ФА), от стоимости которого государство платит процент. Процедура создания Цифрового Финансового Актива (ЦФА) гражданина представляет из себя следующее:

- создается Цифровой Профиль Гражданина (ЦПГ) (сюда включаются данные свидетельства о рождении, данные паспорта, данные ИНН, данные СНИЛС, можно также включить данные школьного аттестата, данные диплома, данные водительского удостоверения, данные полиса ОМС - все данные оцифровываются);

- создается Цифровой профиль материалов дела (ЦПМД);

- создается Цифровой Финансовый Актив (ЦФА).

В-четвертых, когда гражданин Российской Федерации рождается, учится, государство выплачивает пособия, социальные выплаты - по факту это уже Цифровой Финансовый Актив (ЦФА) данного гражданина, что позволяет государству со своей стороны требовать исполнения своих гражданских обязанностей по отношению к государству.

B-пятых, каждый гражданин сам по себе как человек уже несет в себе экономический потенциал для государства. Использование государством его Цифрового Профиля Гражданина (ЦПГ) в своих экономических целях обязывает государство платить гражданину за это использование. Что в свою очередь позволит улучшить благосостояние населения и каждого гражданина в отдельности.

Написан о9 яньаря 2021 года

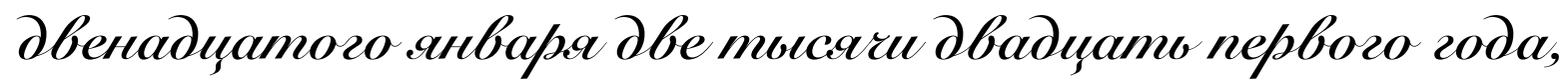
b nятнадуать гасоb нои минут настоящий доқуиент

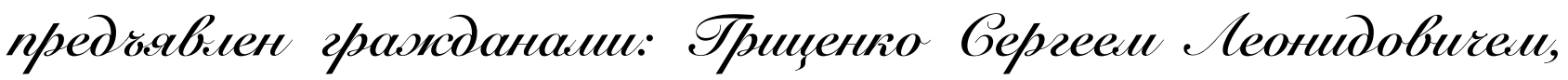

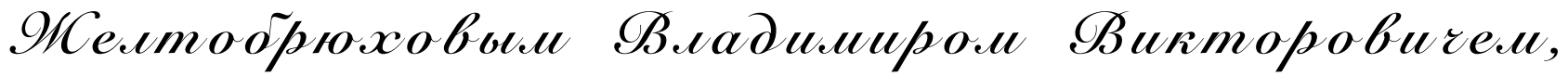
Маркосьянои Яартанош Сафаямовигеш - нотариусу и зареаистрирован b нотариаинои реестре

№ 61/68-re/61-2021-1-1 


\section{«РЕФОРМА МЕДНОЙ МОНЕТЫ В РОССИИ ПО ПРОЕКТУ КНЯЗЯ ПЛАТОНА ЗУБОВА \\ (1796-1797 гг.)}

Автор проекта генерал-фельдцейхмейстер князь Платон Александрович Зубов, в докладе Императрице Екатерине II, преподнесенного 27 апреля 1796 года, констатировалось:

«Все Департаменты без изъятия отягощены расходами, много превышающими их штатное положение, от чего и Государственные Казначейства до сих пор без чрезвычайных пособий государственным надобностям не в состоянии были удовлетворять. Последнее изследование об истинном положении Казначейств открыло, что к 1 генваря 1796 года, старых внутренних долгов и невыполненных указов в разные годы и от одного к другому скопившихся 36973711 руб. 97 коп.

Такое затруднительное в настоящем положение впредь еще будет и тягостнее, есть ли к предупреждению того, паче к истреблению многих неудобств, не принять будет скорые и надежные меры.

Неоспоримо, что возвышение цен на все вещи есть одна из причин сверхштатных расходов, но что более обременяет нуждами государство, Департаменты и частных людей, и тем самым еще более возвышая цены поставляемым в казну вещам, отягощает всех лишними долгами, есть неисправные казною в сроки платежи, разстраивающие доверие Казначейств, доверие каждого Департамента и самое доверие частных людей».

«Дабы поставить государство... в благом и спасительном состоянии, должно будет произвесть в действо операцию в медной монете, и сей есть один способ, которым не токмо без новых налогов и без отягощения всем временным государственным нуждам удовлетворить и от старых долгов очистить возможно будет, но и приведением в соразмерность достоинство монеты сей с торговою ценою меди, пресечь вредное для Государства и для общества изъятие из обращения медной монеты и умаление оной употреблением ея на частные поделки... и при том, возвратить уже давно казною утраченной доход от бития медной монеты, умножением медных денег возстановить соответствие или равновесие между внутренних монет наших, то есть между ассигнациями и медными деньгами, и тем доставить обществу во всем пространстве империи свободнее выменивать ассигнации».

Отрывок взят из книги Управления Федерального казначейства по Нижегородской области « Крепко государство казною...» Нижегородские страницы истории Казначейства России 1779-2007» Изд. Нижний Новгород 2007г. УДК 94 (470.341) ББК 63.3 (2Рос-4Ниж)-2 Е91 Авторы:

А.П. Ефимкин, старший инспектор-делопроизводитель административного отдела Управления Федерального казначейства по Нижегородской области, кандидат экономических наук;

Е.Б. Мазина, руководитель Управления Федерального казначейства по Нижегородской области, государственный советник Российской Федерации III класса, заслуженный экономист России, кандидат экономических наук, доцент. 


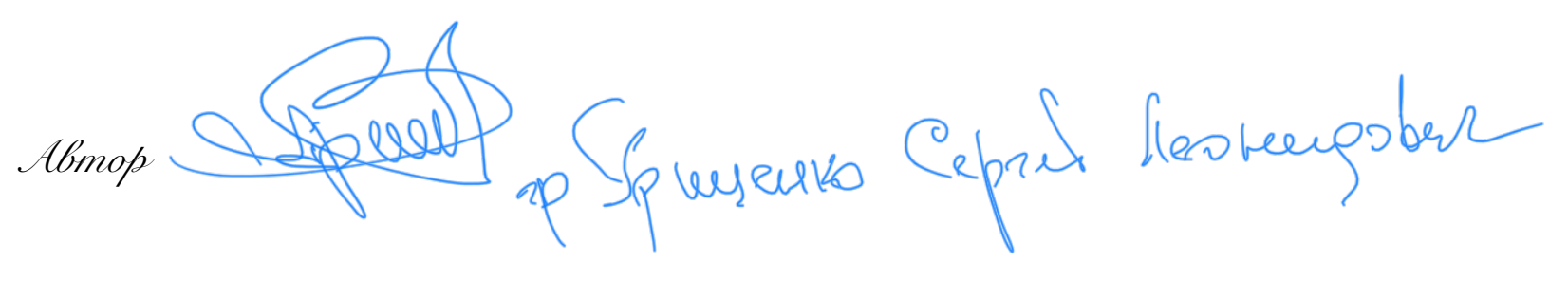

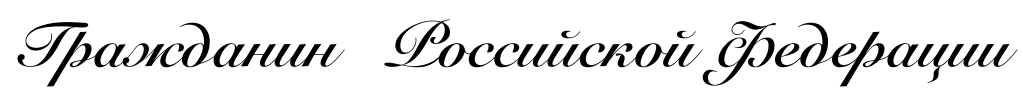

\section{гр Триченко Бергей Сеондовиг}

muтумованный насаедни

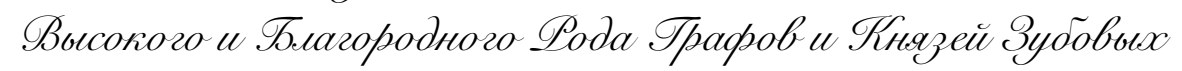

Meritis Grescunt Honores

Non Sibie Sed Tmperio

npopseccop $\mathscr{P}$ AOB. Doctor of Science, Honoris Sausa (T A 1 HO)

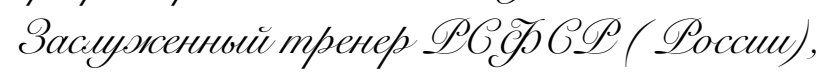

Tавамер Opдена Öкатеринь Вемикой

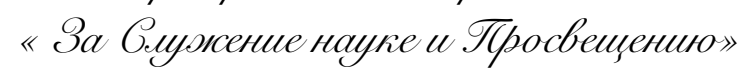

1796-2021 $200(225 \mathrm{~cm})$

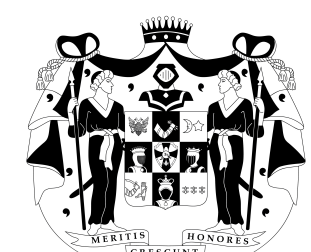

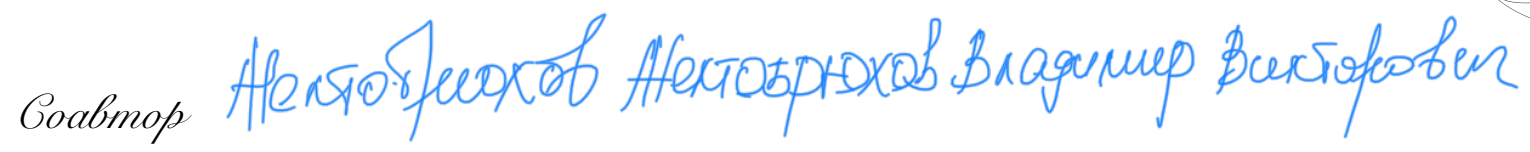

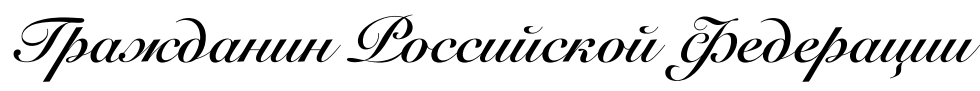

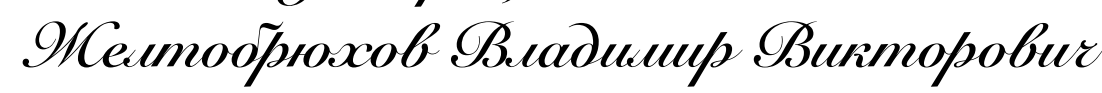

К шоноррафиш по наугной спещиашности

" $O$ pudurecnuе наупи»

uирp спешиашности: 12.00 .06

Земешное прабо; приро доресурсное праһо:

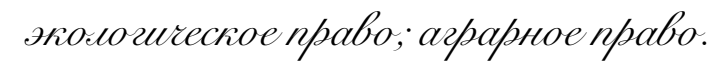

Goabmop

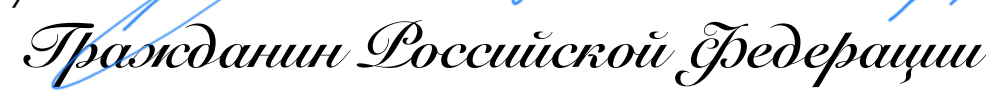

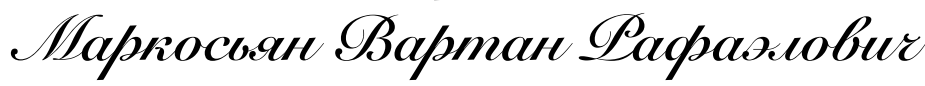

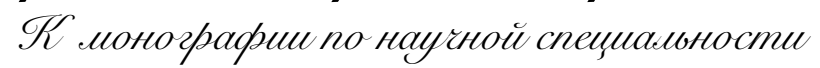

" $О$ рuдигеские науки»

uирр спечиашности: 12.00 .04

Guraridoboe npabo; нaurozobo npabo:

srodscemroe npabo

O1 апреия 2021 года 
24 ucma b propuame Ldf bec 2, \& Mor 